\title{
Evaluasi atas Kebijakan Ekonomi IMF di Indonesia
}

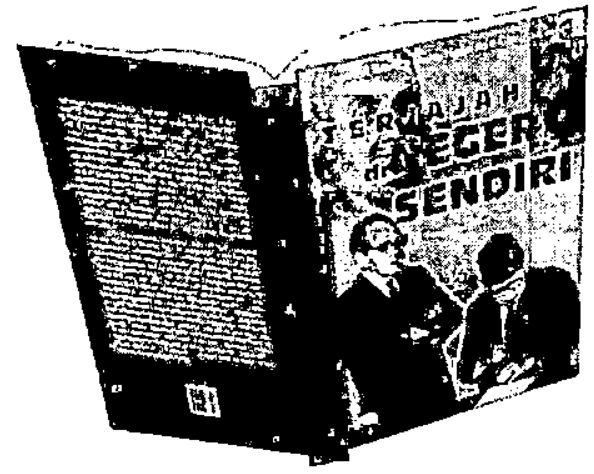

Judul : Terjajah diNegeri Sendiri

Penulis : Revrisond Baswir, Deddy Heriyanto dan Rinto Andriyono

Cetakan : Pertama, April 2003

Penerbit : Elsam, Jakarta

Tebal :xxvi+178 halaman

ISBN : 979-8987-30-6
Krise

risis yang melanda Indonesia pada pertengahan Agustus 1998 sebenarnya sudah ada tanda-tanda penyebab sebelumnya. Hal ini dapat dilihat baik secara eksternal maupun internal. Dari sisi eksternal penyebabnya adalah rentannya Indonesia terhadap kejutan eksternal. Sebagai contoh, krisis ekonomi Indonesia sekarang, kejutan eksternalnya adalah krisis mata uang yang terjadi di Thailand. Dengan melihat rentannya indonesia pada kejutan eksternal sebenarnya krisis tersebut dapat diperkirakan akan melanda beberapa negara di sekitarnya, termasuk Indonesia. Sedangkan dari sisi internal penyebab krisis ekonomi adalah rapuhnya fundamental ekonomi Indonesia. Sentralisasi kekuasaan dan turunannya, seperti penguasaan ekonomi oleh elit penguasa dan crony, industrialisasi pencari rente, korupsi, kolusi dan sebagainya, menyebabkan fundamental ekonomi Indonesia sangat rapuh.
Untuk menanggulangi krisis ekonomi Indonesia, Internationa/Monetary Fund (IMF) diundang masuk ke Indonesia. IMF memiliki dua pola dasar kebijakan yang selalu menjadi prasyarat diberikannya bantuan. Dua pola dasar kebijakan dimaksud adalah, pertama, strucural adjusment policy. Paket kebijakan ini direkomendasikan untuk mengatasi masalah darurat neraca pembayaran. Masalah darurat dimaksud adalah terjadinya defisit transaksi berjalan atau, seperti yang dialami Indonesia tahun 1997, yaitu defisit transaksi berjalan yang menahun dan turunnya nilai mata uang secara drastis. Paket kebijakan yang kedua adalah paket restrukrisasi perekonomian yang beraliran neoliberal. Paket kebijakan ini berisi kebijakan deregulasi yang mengintrodusir perekonomian pasar yang seluas-luasnya.

Paket kebijakan yang pertama terdiri dari empat komponen utama, yaitu (1) liberasi impor, (2) devaluasi, (3) pelaksanaan 
kebijakan moneter dan fiskal di dalam negeri yang terdiri dari pembatasan kredit, pengenaan harga public utilities dan upah yang ditekan agar tetap rendah, dan (4) pemasukan investasi asing yang lebih lancar.

Paket kebijakan kedua terdiri dari empat komponen (1) intervensi pemerintah harus dihilangkan atau diminimumkan oleh karena dianggap telah menimbulkan distorsi pasar (2) privatisasi yang seluas-luasnya dalam ekonomi mencakup sektor-sektor yang dikuasai negara (3) liberalisasi seluruh kegiatan ekonomi dan penghapusan segala jenis proteksi. Ini dimaksudkan untuk menciptakan domestic economic efficiency sehingga harga barang-barang di dalam negeri akan menjalankan fungsi alokasi secara wajar (4) memperbesar dan memperlancar arus masuk investasi asing dengan fasilitas-fasilitas yang lebih luas dan longgar. Dominasi asing dalam pemilihan sosial unit-unit ekonomi baik di sektor swasta maupn di sektor negara harus diperkenankan. Kemudian, bagi orang yang terkena dampak langsung krisis ekonomi dalam bentuk kemiskinan, pengangguran, kelaparan dan penuntunan akses terhadap kesehatan serta pendidikan, IMF. atas desakan dunia internasional menambahkan kebijakan Jaring Pengaman Sosial (Social Safety Net). Atas desakan pemerintah Indonesia, IMF menambahkan kebijakan utang swasta dan kebangkrutan untuk menyelesaikan persoalan kesulitan keuangan para konglemerat dan penguasa swasta nasional (hlm. 18-20).

Pola dasar kebijakan tersebut dikemas IMF ke dalam sebuah dokumen yang disebut Memorandum of Economic and Financial Policy, yang populer disebut letter of Intent (Lol), yang harus disetujui dan dilaksanakan oleh Pemerintah Indonesia. Akhirnya, setelah melalui beberapa perundingan pada tanggal 15 Januari 1998 , IMF dan pemerintah Indonesia mencapai kesepakatan final yang dituangkan dalam Lol yang berisi 50 poin kebijakan ekonomi (hIm.21-22). Akan tetapi apakah resep yang diberikan IMF tersebut dapat memulihkan pemenuhan masyarakat terhadap pangan (right to food), pekerjaan (right to work), pendidikan (right to education), dan kesehatan (right to health)?

Pertanyaan-pertanyaan tersebut merupakan persoalan-persoalan pokok yang menjadi pembahasan buku yang berjudul Terjajah di Negeri Sendiri ini. Buku ini merupakan hasil studi terhadap peran IMF dalam pelanggran hak asasi manusia di Indonesia. Pembahasan dan isi buku ini berangkat dari asumsi dasar yang kemudian menjadi salah satu premis dalam elaborasi penulisnya bahwa pelaku pelanggran hak asasi manusia bukan hanya negara melainkan ada aktor lain selain negara (nonstste actor) yang dengan sendirinya keluar dari pakem konsep hak asasi manusia internasional selama ini yang bersifat statecentric. Aktor yang dimaksud adalah IMF.

Buku yang ditulis oleh Revrisond Baswir, Deddy Heriyanto dan Rinto Andriyono dan diberi kata pengantar oleh Ifdhal Kasim ini terdiri dari tujuh bab pembahasan. Bab I membahas IMF dan Hak Asasi Mnauis di Indonesia. Bab I! menjelaskan Kebijakan yang Mengulang Krisis Evaluasi atas Paradigma Neoliberal IMF, Bab III mendeskripsikan Bila Rakyat hanya Menjadi Budak, Bab IV membahas Kurang Pangan di Negeri Subur, Bab V menguraikan Pendidikan Bukan untuk Rakyat. Bab VI Penyakit Buat Kaum Papa, dan Bab VII Menggagas Gugatan terhadap Kolonialisme Ekonomi.

Buku ini mengajak para pembaca untuk bersikap menggugat keberadaan IMF di negeri ini, minimal mereposisi dan 
meredefinisi eksistensinya. 'Yang lebih penting lagi dari pembahasan buku ini yang merupakan hasil penelitian ketiga penulisnya adalah pemetaan dan analisis terhadap berbagai pelanggaran hak asasi manusia di Indonesia yang tidak bisa dilepaskan dari peran IMF.

Berpijak dari analisis penulis buku ini, bisa disimpulkan bahwa IMF tidak menghasilkan perbaikan ekonomi secara mendasar. Garis kebijakan ekonomi yang disarankan oleh IMF justru mengarah pada sebuah struktur perekonomian yang memunculkan ketergantungan ekonmi Indonesia pada utang luar negeri dan investasi asing, yang terjadi adalah apa yang disebut dengan kolonialime ekonomi. Di samping itu, juga kebijakan IMF menyebabkan berulangnya pelanggaran hak asasi manusia. Pelanggaran tersebut untuk masing-masing pemenuhan hak adalah hak atas pekerjaan, hak atas pangan, hak atas pendidikan, dan hak atas kesehatan (hlm.129-130).

Untuk menghadapi persoalan-persoalan yang timbul sebagai dampak kebijakan pembangunan yang diarahkan IMF, penulis buku ini menyarankan perlu dipertimbangkan sejumlah agenda mendesak, yaitu (1) penghapusan atau peringanan jumlah dan penundaan pembayaran utang luar negeri Indonesia, (2) bantuan yang disalurkan melalui IMF harus betul-betul mencerminkan kebutuhan masyarakat, (3) untuk bantuan yang sudah terlanjur dicairkan, termasuk untuk program JPS, IMF harus mempertanggungjawabkan realisasinya bersama-sama pemerintah Indonesia, yang telah mendesain kebijakan tersebut, (4) IMF yang sudah terlanjur berkiprah di Indonesia, harus mempertimbangkan persoalan kemandirian perekonomian Indonesia.

Di samping itu, penulis buku ini juga menggagas bahwa politik pembangunan kerakyatan memang tidak didasarkan pada paradigma lokomotif, melainkan pada paradigma fondasi. Artinya, melalui politik pembangunan kerakyatan, pelaksanaan pembangunan di Indonesia tidak lagi berada di tangan segelintir elite kekuasaan dan kroninya, melainkan bertumpu pada partisipasi masyarakat dan kemandirian ekonomi. Dengan partisipasi tersebut, masyarakat akan lebih terangkat posisinya dalam perekonomian, sehingga dapat menikmati standar hidup yang lebih tinggi. Seiring dengan hal itu, hak-hak masyarakat atas pekerjaan, pangan, pendidikan dan kesehatan tidak akan terabaikan (hlm.132134).

Walaupun sangat terlambat, keputusan pemerintah Indonesia untuk lepas dari IMF masih lumayan daripada tidak sama sekali: Seharusnya, sejak awal pemerintah Indonesia tidak perlu minta bantuan kepada IMF untuk mengatasi krisis moneter di Indonesia yang terjadi sejak 1997.Sejak awal, sudah banyak pihak yang mengingatkan pemerintah indonesia untuk tidak menggandeng IMF. Karena beberapa negara Amerika Latin yang telah menerima bantuan IMF dengan resep-resepnya ternyata tidak jitu. Bahkan, kondisi perekonomian negara -negara tersebut semakin parah.

Di Indonesia sendiri, kita melihat, betapa resep yang diberikan IMF kepada pemerintah telah membuat tarif BBM dan listrik naik berlipat-lipat, subsidi pendidikan dicabut, sehingga biaya sekolah melangit.Masih banyak lagi kebijakan yang membuat kondisi -tidak saja perekonomian, tetapi juga pendidikan dan sektor lainnya menjadi morat-marit.

Buku ini menarik untuk dibaca oleh berbagai kalangan, terutama bagi akademisi, mahasiswa, pengamat ekonomi dan khalayak umum karena isinya aktual, 